\title{
Pelaksanaan Pembinaan Narapidana Anak Pada Lembaga Pemasyarakatan Di Provinsi Sulawesi Tenggara
}

\author{
Arifai \\ Fakultas Hukum, Universitas Muhammadiyah Kendari \\ Koresponden, Email: arifai171278@gmail.com
}

\begin{abstract}
ABSTRAK
Tujuan penelitian menganalisis pelaksanaan pembinaan narapidana anak pada lembaga pemasyarakatan di Provinsi Sulawesi Tenggara. Jenis penelitian yang akan dilakukan adalah penelitian deskriptif dengan tipe penggabungan antara penelitian hukum normatif dengan penelitian hukum sosiologis yang terkait pelaksanaan pembinaan anak narapidana di Provinsi Sulawesi Tenggara. Hasil penelitian menunjukkan bahwa Pelaksanaan pembinaan narapidana anak pada lembaga pemasyarakatan di Provinsi Sulawesi Tenggara yang meliputi pembinaan kepribadian dan kemandirian, hal itu akan memberikan dampak yang kurang baik kepada anak narapidana ketika melakukan reintegrasi dengan masyarakat yang diberi stigma negatif oleh masyarakat. Rekomendasi penelitian hendaknya para Pimpinan di instansi LPKA, Lapas dan Rutan untuk memaksimalkan Kerjasama dengan intansi terkait dalam rangka pembinaan narapidana anak dalam menjalani hukuman pada lembaga pemasyarakatan di Provinsi Sulawesi Tenggara.
\end{abstract}

Kata Kunci: Pembinaan; Narapidana; Anak

\begin{abstract}
The research objective was to analyze the implementation of the development of child prisoners in prisons in Southeast Sulawesi Province. The type of research to be carried out is descriptive research with the type of combining normative legal research with sociological legal research related to the implementation of child prisoners in Southeast Sulawesi Province. The results showed that the implementation of coaching child prisoners in prisons in Southeast Sulawesi Province which includes personality and independence development, will have an adverse impact on child prisoners when reintegrating with a community that is given a negative stigma by society. Research recommendations should be made by leaders in LPKA, prisons and detention centers to maximize collaboration with related institutions in the framework of fostering child prisoners in serving sentences in prisons in Southeast Sulawesi Province.
\end{abstract}

Keywords: Coaching; Prisoners; Child 


\section{PENDAHULUAN}

Secara konseptual anak yang berhadapan dengan hukum (children in conflict with the law) menurut Undang No 11 Tahun 2012 tentang Sistem Peradilan Pidana Anak (UU SPPA) adalah anak yang berkonflik dengan hukum, anak yang menjadi korban tindak pidana, dan anak yang menjadi saksi tindak pidana (Nugroho, 2017). Sementara Anak yang berkonflik dengan hukum adalah anak yang telahberumur 12 (dua belas) tahun tetapi belum berumur 18 (delapan belas) tahun yang diduga melakukan tindak pidana. Sedangkan Pasal 37 ayat b KHA yang berbunyi “Tidak seorang anak pun akan dirampas kemerdekaannya secara tidak sah dan sewenangwenang (Ningtias, Sampara \& Djanggih, 2020). Penangkapan, penahanan, atau penghukuman seorang anak harus sesuai dengan hukum, akan diterapkan sebagai upaya terakhir (last resort), dan untuk jangka waktu yang paling pendek". Dalam Pasal 37 ayat c KHA dinyatakan "Setiap anak yang dirampas kemerdekaannya akan diperlakukan secara manusiawi, dihormati martabat kemanusiaannya, dan dengan memperhatikan kebutuhan-kebutuhan anak seusianya" (Erwandi, 2020).

Pasal 85 UU SPPA mengatur ketentuan tentang anak yang dijatuhi pidana (tahap pasca adjudikasi). Berbeda dengan UU Pengadilan anak, di mana anak yang dipidana ditempatkan di LAPAS Anak, dalam UU SPPA ini anak yang dijatuhi pidana penjara ditempatkan di Lembaga Pembinaan Khusus Anak (LPKA) (Chanda, 2020). Pada tahap ini anak juga mendapat hak yang sama dengan tahap adjudikasi. Jangka waktu pemidanaan di LPKA ada batasnya, yaitu jika anak belum selesai menjalani pidana di LPKA namun telah mencapai umur 18 (delapan belas) tahun dipindahkan ke Lembaga Pemasyarakatan Pemuda, dan jika telah mencapai umur 21 (dua puluh satu) tahun tetapi belum selesai menjalani pidana anak dipindahkan ke Lembaga Pemasyarakatan dewasa dengan memperhatikan kesinambungan pembinaan anak (Wibowo, 2018).

Berdasarkan Undang-Undang Nomor 12 Tahun 1995 tentang Pemasyarakatan (UU Pemasyarakatan), anak yang dibina dan dididik di Lembaga Pemasyarakatan disebut Anak Didik Pemasyarakatan, terdiri atas Anak Pidana, Anak Sipil dan Anak Negara. Anak Pidana yaitu anak yang berdasarkan keputusan pengadilan menjalani pidana di Lembaga Pemasyarakatan Anak, paling lama sampai umur 18 tahun (Situmorang, 2019). Anak Negara yaitu anak yang berdasarkan keputusan pengadilan diserahkan pada negara dan dididik dan ditempatkan di Lembaga Pemasyarakatan Anak, paling lama sampai berumur 18 tahun. Anak sipil adalah anak yang atas permintaan orang tua atau wali memperoleh penetapan pengadilan untuk dididik di Lembaga Pemasyarakatan Anak paling lama sampai berumur 18 Tahun (Pasal 1 angka 8 UU Pemasyarakatan).

Perlindungan terhadap anak yang terkena kasus hukum (narapidana anak) harus dibedakan dengan penanganan terhadap orang dewasa. Karena adanya perbedaan karakter fisik maupun psikis yang dimiliki oleh anak dengan orang dewasa (Haling, et,al. 2018). Maka dari itu, keberadaan Lembaga Pemasyarakatan dalam konteks pembinaan narapidana anak, seharusnya menuntut dua unsur, yaitu: Unsur perubahan sikap, mental dan perilaku anak kearah yang lebih baik, dan; Unsur perubahan perpektif negatif masyarakat terhadap ex narapidana anak, sehingga masyarakat secara normal dapat menerima kembali mantan narapidana anak daalam lingkungan pergaulannya (Rukmana, 2020).

Pembinaan terhadap anak didik pemasyarakatan harus mendapat perhatian yang khusus agar anak tersebut dapat menyadari kesalahan yang telah diperbuatnya dan tidak mengulanginya lagi. Pembinaan di Lembaga Pemasyarakatan merupakan salah satu langkahyang dilakukan 
untuk merubah pribadi anak menjadi lebih baik, lebih bermoral dan dapat diterima kembali ditengah masyarakat (Haryaningsih \&Haryati, 2020).

Lembaga pemasyarakatan merupakan lembaga yang dibentuk oleh negara untuk membina masyarakat yang perlu pembinaan karena mereka telah melakukan kejahatan atau pelanggaran hukum yang berlaku ditengah masyarakat. Lembaga pemasyarakatan dianggap dapat memberikan pembinaan karena tujuan utama dari pemasyarakatan adalah untuk menjadikan pelaku tidak mengulangi lagi perbuatannya (Michael, 2017). Maka harus dilakukan sistem pembinaan yang tepat dan sesuai dengan kondisi narapidana tersebut, terlebih untuk narapidana anak. Karena menurut Undang-Undang Perlindungan Anak di Indonesia, anak harus diperlakukan berbeda dengan orang dewasa ketika berhadapan dengan hukum (Fitriani, 2016). Hal ini bertujuan untuk menghindari terganggunya psikis anak dan perkembangan mentalnya ketika nanti selesai menjalani proses hukum. Jadi petugas di Lembaga Pemasyarakatan harus dengan sabar dalam memberi pelajaran yang tepat bagi narapidana anak .

Berdasarkan data dari Sistem Database Pemasyarakatan, Bulan Desember 2018, tercatat 2338 anak yang dipidana. Provinsi yang paling banyak anak dipidana, adalah Prov. Jawa Timur sebanyak 281 anak, Prov. Lampung 209, Prov. Sumatera Utara 18o anak, Prov. Sumatera Selatan 174 anak, Prov. Sulawesi Selatan 165 anak. Prov. Gorontalo tidak anak yang dipidana penjara, sementara Provinsi Sulawesi Tenggara sebanyak 36 anak.

Menurut Kanya Eka Santi, Direktur Rehabilitasi Sosial Anak pada Kemensos RI, bahwa anak yang memiliki persoalan dengan hukum menjadi perhatian Kementerian Sosial, sebab jumlahnya terus meningkat. Sebanyak 2.200 kasus anak berhadapan dengan hukum terdata hingga Desember 2018. Kemudian pada Juli 2019 jumlahnya naik menjadi 3.000 kasus. Oleh karen itu, perlu penanganan khusus untuk memberikan perhatian kepada anak-anak itu.

Menurut Direktur Analisa Peraturan Perundang-undangan Bappenas, Diani Sadia Wati, alasan perubahan Undang-Undang Nomor 3 Tahun 1997 tentang Pengadilan Anak Menjadi Undang-Undang Nomor 11 Tahun 2012 tentang Sistem Peradilan Pidana Anak (UU SPPA) disebabkan beberapa hal sebagai berikut: Pertama, kegagalan sistem peradilan pidana anak untuk menghasilkan keadilan; Kedua, tingkat tindak pidana dan residivisme anak tidak mengalami penurunan; Ketiga, proses peradilan gagal memperlakukan anak; keempat, pengadilan lebih banyak memanfaatkan pidana perampasan kemerdekaan (pidana penjara) daripada bentuk sanksi lainnya; dan kelima, pendekatan yang terlalu legalistik.

Menurut Pengamat sosial Samsuddin mengatakan pertambahan jumlah binaan dari kalangan perempuan dan anak setiap tahun patut menjadi perhatian karena menggambarkan buruknya pembinaan mental mereka. Beragam faktor penyebab perempuan dan anak terlibat kasus hukum, antara lain, kesenjangan ekonomi, lemahnya pembinaan mental dan tidak peduli Pendidikan. Pemerintah Provinsi Sulawesi Tenggarsa mendukung pembangunan Lapas Perempuan dan Anak dengan menyiapkan lahan seluas 5 hektare di kawasan Nanga Nanga. Dari tahun ke tahun menunjukan peningkatan, baik kasus narkoba, penipuan, pencurian, hingga penganiayaan.

Berdasarkan hasil pra penelitian di lapangan, masih ada anak yang ditempakan Bersama dengan orang dewasa di Rumah Tahana dan Lempaga Pemasyarakatan. Keberadaan anak dalam tempat penahanan dan lembaga pemasyarakatan bersama sama dengan orang dewasa menempatkan anak pada situasi rawan menjadi korban berbagai tindakan kekerasan. Oleh karena itu, dibutuhkan perhatian dan upaya yang kuat meminimalkan kerugian yang dapat 
diderita oleh anak yang terpaksa berhadapan dengan proses hukum dalam sistem peradilan pidana.

\section{METODE PENELITIAN}

Jenis penelitian ini adalah penelitian yuridis empiris. Penelitian ini dilaksanakan di Propinsi Sulawesi Tenggara dan secara khusus akan dipilih dan ditetapkan di tiga kabupaten/kota masing masing sebagai representasi keterwakilan dari Kabupaten/kota yang ada di Propinsi Sulawesi Tenggara, yaitu Kota Kendari, Kabupaten Konawe, dan Kabupaten Kolaka. Dipilihnya kabupaten/kota tersebut dengan pertimbangan serta alasan rasional dan obyektif bahwa ketiga Kabupaten/kota tersebut sebagai representasi keterwakilan kabupaten/Kota di Propinsi Sulawesi Tenggara serta berdasarkan hasil pengamatan Kabupatean/kota tersebut pembinaan narapidana anak di lembaga pemasyarakatan belum optimal. Data tentang implementasi pembinaan narapidana anak diperoleh dari Lapas dan Bapas masing masing kabupaten/kota tersebut dari Tahun 2017 sampai dengan Tahun 2019, serta kuesioner dan wawancara langsung dengan petugas lembaga pemasyarakatan, dan narapidana anak.

\section{PEMBAHASAN}

\section{A. Pelaksanaan Pembinaan Narapidana Anak Pada Lembaga Pemasyarakatan Di Provinsi Sulawesi Tenggara}

Secara konseptual anak yang berhadapan dengan hukum (children in conflict with the law) menurut UU SPPA adalah anak yang berkonflik dengan hukum, anak yang menjadi korban tindak pidana, dan anak yang menjadi saksi tindak pidana. Sementara Anak yang berkonflik dengan hukum adalah anak yang telah berumur 12 (dua belas) tahun tetapi belum berumur 18 (delapan belas) tahun yang diduga melakukan tindak pidana.

Di tiga lokasi penelitian yaitu Kabupaten Kolaka, Kota Kendari, dan Kabupaten Konawe, terdapat gambaran mengenai anak yang berhadapan dengan hukum, selengkapnya dapat dilihat pada tabel di bawah ini:

Tabel 1 Jumlah Anak yang Berhadapan Dengan Hukum di Tiga Lokasi Penelitian Dari Tahun 2017 s/d 2019

\begin{tabular}{|c|c|c|c|c|c|c|c|}
\hline \multirow{3}{*}{ No. } & \multirow{3}{*}{ Tahun } & \multicolumn{6}{|c|}{ Kabupaten/Kota } \\
\hline & & \multicolumn{2}{|c|}{ Kolaka } & \multicolumn{2}{|c|}{ Kendari } & \multicolumn{2}{|c|}{ Konawe } \\
\hline & & $\mathbf{F}$ & $\%$ & $F$ & $\%$ & $\mathbf{F}$ & $\%$ \\
\hline 1. & 2017 & 8 & 47,05 & 75 & 56.81 & 6 & 20.68 \\
\hline 2. & 2018 & 6 & 35,29 & 29 & 21.96 & 10 & 34.48 \\
\hline \multirow[t]{2}{*}{3} & 2019 & 3 & 17,64 & 28 & 21.21 & 13 & 44.82 \\
\hline & Jumlah & 17 & 100,00 & 132 & 100,00 & 29 & 100,00 \\
\hline
\end{tabular}

Sumber: Data Kanwil Kemenkun HAM Prov. Sultra yang sudah dilolah, 2020

Berdasarkan data di atas menunjukkan bahwa, sejak tiga tahun terakhir (2017 s/d 2019), di tiga lokasi penelitian, sebanyak 178 anak yang berhadapan dengan hukum. LPKA Kota Kendari terbanyak membina anak yang berhadapan dengan hukum, yaitu 132 anak atau sebesar 74,15 \%, kemudian Rumah Tahanan Kabupaten Konawe sebanyak 29 atau sebesar 16,29 \% dan Rumah Tahanan Kabupaten Kolaka sebanyak 17 atau sebesar 9,55\%. 
Apabila dilihat dari persentase setiap tahunnya, di tiga lokasi penelitian, tahun 2017 sebanyak 89 anak yang berhadapan dengan hukum atau sebesar 50 \%; Tahun 2018 sebanyak 45 anak yang berhadapan dengan hukum atau sebesar 25,28 \%; dan Tahun 2019, sebanyak 44 anak yang berhadapan dengan hukum atau sebesar 24,71 \%. Di Kabupaten Kolaka, terjadi penurunan anak yang bderhadapan dengan hukum setiap tahun, begitu pula di Kabupaten Kendari. Sebaliknya di Kabupaten Konawe terjadi peningkatan setiap tahun.

Adapun bentuk-bentuk pembinaan anak di rumah tahanan dan LPKA di lokasi penelitian, dapat diuraikan di bawah ini:

\section{Pembinaan Kepribadian}

Lembaga pemasyarakatan sebagai salah satu wadah pembinaan narapidana juga berfungsi sebagai lembaga pendidikan yang dapat meningkatkan nilai tambah bagi narapidana dengan memberikan program pembinaan kerohanian dan kemandirian, berupa pelatihan berbagai keterampilan dan bimbingan kerohanian sebagai bekal bagi narapidana untuk kembali ke masyarakat.

Pembinaan kepribadian narapidana dalam adalah suatu program yang dilaksanakan oleh Lembaga Pemasyarakatan dalam rangka untuk menumbuhkan kepercayaan dan kemampuan diri para narapidana supaya bisa kembali diterima oleh masyarakat setelah habis masa hukumannya serta bisa bersikap dan berperilaku sesuai dengan norma-norma yang berlaku dalam masyarakat. Pembinaan kepribadian ini terdiri dari ceramah agama, pengajian Al Qur'an, belajar pendidikan umum dan pengamalan Pancasila.

Apabila dicermati pembinaan kepribadian amatlah penting karena berkaitan erat dengan perubahan pada watak dan mental dari narapidana sendiri, pembinaan ini yang nantinya banyak berpengaruh terhadap perubahan dari dalam diri narapidana tersebut apakah nantinya dapat menjadi warga binaan yang sesuai dengan tujuan dari pemasyarakatan itu sendiri. Pembinaan kepribadian sendiri tidaklah mudah, karena untuk mempengaruhi bahkan mengubah watak atau mental seseorang itu sulit perlu adanya pedoman dan cara-cara tertentu yang dilakukan oleh petugas agar dapat mengubah sedikit demi sedikit kepribadian dari narapidana. Pembinaan kepribadian ini diharapkan dapat membentuk watak dan mental yang baru bagi narapidana agar menjadi manusia yang baru yang dapat bertanggung jawab atas kejahatan yang pernah mereka lakukan dan untuk menghindari untuk melakukan kejahatan lagi. Oleh karena itu pembinaan kepribadian amatlah penting untuk membangun watak dan mental baru bagi narapidana agar menjadi lebih baik lagi.

Tabel 2 Pelaksanaan Pembinaan Kepribadian Narapidana Anak

\begin{tabular}{|c|c|c|c|c|c|c|}
\hline \multirow{2}{*}{ No. } & \multirow{2}{*}{\multicolumn{2}{|c|}{ Pembinaan Kepribadian }} & \multicolumn{2}{|c|}{ Narapidana } & \multicolumn{2}{|c|}{ Tahanan } \\
\hline & & & $\mathbf{F}$ & $\%$ & $\bar{F}$ & $\%$ \\
\hline 1. & Keagamaan & & 21 & 100 & 12 & 100 \\
\hline 2. & Olah Raga & & 6 & 28,57 & - & - \\
\hline 3. & Kesenian & & - & - & - & - \\
\hline 4. & $\begin{array}{l}\text { Kesadaran } \\
\text { Bernegara }\end{array}$ & Berbangsa & 21 & 100 & 12 & 100 \\
\hline
\end{tabular}

Sumber: Data Kanwil Kemenkun HAM Prov. Sultra yang sudah dilolah, 2020

Berdasarkan data di atas menggambarkan bahwa pembinaan kepribadian yang di Wilayah Hukum Kanwil Kemenkum Ham Provinisi Sulawesi Tenggara ada empat jenis pembinaan 
kepribadian yang dilakukan yaitu, keagamaan, olah raga, kesenian, dan kesadaran berbangsa dan bernegara. Di antara empat pembinaan kepribadian pembinaan keagamaan dan kesadaran berbangsa dan bernegara diikuti oleh seluruh narapidana dan tahanan anak, sementara pembinaan olah raga hanya diikuti $6(28,57)$ narapidana dan tahanan anak. Untuk pembinaan kesenian tidak ada narapidana dan tahanan anak yang mengikutinya.

Berdasarkan Keputusan Menteri Kehakiman RI. No. M. 02.PK.o4 tanggal 10 April 1990 tentang Pola Pembinaan Narapidana/Tahanan pada BAB VII tentang pelaksanaan pembinaan dibagi menjadi 5 yaitu: pembinaan kesadaran beragama, pembinaan inteletual, pembinaan kesadaran berbangsa, dan bernegara, pembinaan kesadaran hukum, pembinaan pengintegrasian, sementara di Wilayah hukum Kanwil Kemenkum Ham Provinisi Sulawesi Tenggara dilaksanakan pembinaan keagamaan, olah raga, kesenian, dan kesadaran berbangsa dan bernegara yang uraiannya sebagai berikut:

\section{Pembinaan keagamaan}

Pembinaan kesadaran beragama merpakan usaha ini diperlukan agar dapat diteguhkan imannya terutama memberi pengertian agar narapidana anak dapat menyadari akibat-akibat dari perbuatan-perbuatan yang benar dan perbuatan-perbuatan yang salah (Amran, Pawennei \& Zainuddin, 2020). Pembinaan kesadaran berbangsa dan bernegara, dengan menyadarkan narapidana agar dapat menjadi warga negara yang baik yang dapat berbakti bagi bangsa dan negaranya. Perlu disadarkan bahwa berbakti untuk bangsa dan negara adalah sebahagian dari iman (taqwa).

Untuk mengetahui pelaksanaan pembinaan keagamaan di LPKA/Lapas dan Rutan dapat dilihat pada tabel di bawah ini:

\section{Tabel 3 Pelaksanaan Pembinaan Keagamaan}

\begin{tabular}{clcc} 
No. & \multicolumn{1}{c}{ Pernyataan } & Frekuensi & Persentase (\%) \\
\hline $\mathbf{1}$ & Selalu Dilaksanakan & 3 & 6,66 \\
2 & Kadang-kadang Dilaksanakan & 26 & 57,77 \\
3 & Jarang Dilaksanakan & 13 & $\mathbf{2 8 , 8 8}$ \\
4 & Tidak pernah Dilaksanakan & - & - \\
5 & Ragu-Ragu/Tidak Tahu & 3 & 6,66 \\
\hline & J u m $\mathbf{~} \mathbf{~ a ~ h ~}$ & $\mathbf{4 5}$ & $\mathbf{1 0 0 , 0 0}$ \\
\hline
\end{tabular}

Sumber: Data primer yang diolah, 2020

Berdasarkan data di atas menggambarkan bahwa faktor faktor besar responden menyatakan kadang-kadang dilaksanakan pembinaan keagamaan terhadap narapidana anak yang dilaksanakan oleh Lapas atau Rutan.

Menurut Herianto, Kepala Seksi Bimbingan Napi dan Anak Didik, Lembaga Pemasyarakatan (Lapas) Kelas IIA Kendari, bahwa pembinaan keagamaan mampu membentuk mental positif bagi narapidana yang bertujuan meningkatkan kesadaran melaksanakan ajaran-ajaran agama dan meningkatkan pengetahuan agama anak. Selain itu, melalui pembinaan keagamaan itu, dapat memantapkan faktor harga diri dan kepercayaan diri dari warga binaan. Ada enam pilar karakter yang dapat dibentuk melalui pembinaan keagamaan bagi setiap narapidana, yakni kejujuran, rasa percaya diri, rasa hormat, rasa tanggungjawab, rasa kepedulian dan toleransi. Karakter tersebut tidak bisa ditanamkan dengan serta merta pada diri narapidana, namun 
diperlukan program pembinaan yang sistematis dan berkesinambungan (Wawancara, 23 Februari 2020).

Menurut Kepala Rasid Margono, Kepala LPKA Kelas II Kendari, menyatakan dari sekitar 40 orang yang menghuni Lapas anak, 40 persen diantaranya karena terjerat kasus begal. Pada umumnya rata-rata dihukum 1 sampai 2 tahun lebih. Ada 40 tahanan anak, sekitar 30 s.d 40 persen karena kasus begal. Napi anak kasus begal di LPKA Kendari ini merupakan tertinggi selama ini. Kegiatan Pembinaan rohani Anak dilaksanakan di Musholla berupa pengajian Iqra dan Alquran Dibantu oleh Tenaga Dai, Mubaligh/ustadz/ah dari pihak lapas dan dari luar seperti WIBER, Yayasan Nirunabi, dan GenBi.

Lapas dan Rutan memilih melakukan pembinaan keagamaan, sebagai upaya untuk merehabilitasi moral dan mental serta dapat meningkatkan iman sebagai bentuk karakter dari warga binaan yang ada di Lapas tersebut. Pembinaan keagamaan, dapat membangkitkan rasa kepercayaan terhadap Tuhan serta dapat menyadarkan napi dari perbuatan yang melanggar hukum. Berbagai metode dalam pembinaan keagamaan bagi para napi untuk mencapai sasaran serta tujuan dari pembinaan keagamaan telah dilakukan Lapas kelas IIA Kendari.

Hasil penelitian di lapangan bahwa faktor pembinaan yang telah dilakukan Lapas dan Rutan tersebut yakni berupa Baca Tulis Al-Qur'an, Shalat Jum'at, Ceramah, Pesantren, dan Peringatan Hari Besar Islam. Materi pembinaan berkisar tentang aqidah atau keimanan, keislaman atau faktor, dan materi akhlak atau budi pekerti. Materi-materi tersebut disampaikan pada kegiatan pembinaan sesuai dengan jadwal yang telah dibuat Kasi Bim Napi dan anak didik. Pembinaan keagamaan sangat penting untuk mencapai sepuluh prinsip pemasyarakatan, sehingga pada akhirnya narapidana yang dibina di Lapas bisa menjadi manusia yang memiliki mental dan moralitas yang baik. Di samping itu integrasi pembinaan kepribadian dan pembinaan kemandirian juga dapat terwujud dengan baik.

\section{Pembinaan Olahraga}

Undang-Undang Republik Indonesia No. 3 Tahun 2005 tentang Sistem Keolahragaan Nasional (Siskornas) menyebutkan bahwa tujuan olahraga adalah memelihara dan meningkatkan faktor dan kebugaran, prestasi, kualitas manusia, menanamkan nilai moral dan akhlak mulia, sportivitas, disiplin, mempererat dan membina persatuan dan kesatuan bangsa, memperkokoh ketahanan nasional sefta mengangkat harkat, martabat dan kehormatan bangsa. Oleh karena itu, olahraga sangat diperlukan bagi setiap umat manusia.

Pembinaan olahraga rutin merupakan pembinaan fisik bagi WBP yang dilaksanakan di Lapas, dan Rutan. Kegiatan dilakukan secara terjadwal dan berkesinambungan yang disesuaikan dengan keadaan dan kondisi masingmasing Lapas dan Rutan setempat. Jenis olahraga rutin yang dapat dilakukan antaralain senam pagi, voli, tenis meja, bulu tangkis, catur, futsal/sepak bola.

Untuk mengetahui pelaksanaan pembinaan olah raga di Lapas dan Rutan, dapat dilihat pada faktor di bawah ini: 
Tabel 4 Pelaksanaan Pembinaan Olahraga

\begin{tabular}{clcc} 
No. & \multicolumn{1}{c}{ Pernyataan } & Frekuensi & Persentase (\%) \\
\hline 1 & Selalu Dilaksanakan & 2 & $\mathbf{2 , 2 2}$ \\
2 & Kadang-kadang Dilaksanakan & 6 & 13,33 \\
3 & Jarang Dilaksanakan & 32 & 71,11 \\
4 & Tidak pernah Dilaksanakan & 2 & $\mathbf{2 , 2 2}$ \\
5 & Ragu-Ragu/Tidak Tahu & 3 & 6,66 \\
\cline { 3 - 4 } & J u m l a h & $\mathbf{4 5}$ & $\mathbf{1 0 0 , 0 0}$ \\
\hline
\end{tabular}

Sumber: Data primer yang diolah, 2020

Berdasarkan data menggambarkan bahwa sebagai besar responden mengatakan bahwa pembinaan inteletual tidak selalu dilaksanakan (71,11\%). Pembinaan kemampuan intelektual bagi para narapidana anak di Lembaga Pemasyarakatan dan Rutan belum dilaksanakan secara maksimal.

Pembinaan olahraga di LPKA, Lapas dan Rutan di Wilayah Hukum Kanwil Kementerian Hukum dan HAM Provinsi Sulawesi Tenggara yang disediakan adalah Sepak Bola, Futsal, Tennis Meja, Bulu Tangkis, Bola Voly, Senam Sehat, Tenis Lapangan, Catur, Takraw dan Olah Raga Tradisional. Olahraga Senam Sehat merupakan olahraga yang wajib diiikuti oleh seluruh warga binaan dan hanya olah raga senam sehat inilah satu-satunya cabang olah raga yang diikuti oleh narapidana/tahanan anak. Pembinaan ini bertujuan untuk menjaga faktor dan kebugaran tahanan sekaligus mengasah bakat-bakat yang dimiliki oleh tahanan, juga menjalin hubungan yang harmonis antara petugas Rutan dan tahanan untuk mendukung proses pembinaan. Seperti yang diungkapkan oleh salah seorang narapidana anak bahwa: Pembinaan jasmani atau olahraga, senam pagi setiap hari Sabtu pukul o7:30-o8:30 senam pagi ini wajib diikuti oleh semua tahanan/narapidana

\section{Pembinaan kesenian}

Kesenian adalah bagian dari budaya dan merupakan sarana yang digunakan untuk mengekspresikan rasa keindahan dari dalam jiwa manusia. Selain mengekspresikan rasa keindahan dari dalam jiwa manusia, kesenian juga mempunyai fungsi lain. Oleh karena itu, pembinaan bidang kesenian di Lembaga Pemasyarakatan/Rumah Tahanan Negara merupakan kegiatan yang dapat memulihkan jiwa warga binaan pemasyarakatan faktor faktor yang lebih baik.

Untuk mengetahui pelaksanaan pembinaan kesenian di Lapas dan Rutan, dapat dilihat pada tabel di bawah ini:

\section{Tabel 5 Pelaksanaan Pembinaan Kesenian}

\begin{tabular}{clcc} 
No. & \multicolumn{1}{c}{ Pernyataan } & Frekuensi & Persentase (\%) \\
\hline $\mathbf{1}$ & Selalu Dilaksanakan & - & - \\
$\mathbf{2}$ & Kadang-kadang Dilaksanakan & - & - \\
3 & Jarang Dilaksanakan & - & - \\
4 & Tidak pernah Dilaksanakan & 35 & 77,77 \\
5 & Ragu-Ragu/Tidak Tahu & 10 & $\mathbf{2 2 , 2 2}$ \\
\hline & J u m la h & $\mathbf{4 5}$ & $\mathbf{1 0 0 , 0 0}$ \\
\hline
\end{tabular}

Sumber: Data primer yang diolah, 2020 
Berdasarkan data di atas menggambarkan bahwa Sebagian besar responden menyatakan untuk pembinaan kesenian bagi narapidana anak tidak pernah ada kegiatan yang dilakukan, kecuali untuk narapidana orang dewasa itu pun jenis kesenian seni suara yang diikuti oleh narapidana orang dewasa. Pembinaan dalam bidang kesenian ditujukan untuk narapidana yang ingin mengisi waktu luangnya yang tujuannya untuk menghibur diri narapidana.

5. Pembinaan kesadaran berbangsa dan bernegara

Usaha ini dilaksanakan melalui pembinaan pengenalan Pancasila. Untuk itu pembinaan ini diberikan dengan tujuan untuk menumbuhkan kesadaran berbangsa dan bernegara dalam diri para narapidana. Dengan tumbuhnya kesadaran berbangsa dan bernegara, diharapkan setelah para narapidana keluar dari Lembaga Pemasyarakatan, mereka dapat menjadi warga binaan yang baik dapat memberikan sesuatu yang berguna bagi bangsa dan negaranya.

Pembinaan kesadaran berbangsa dan bernegara ini dilakukan oleh Lapas Anak dan Rutan pada saat masa orientasi Anak masuk ke Lapas Anak Kendari, yaitu pada masa Admisi Orientasi $(\mathrm{AO})$ yang dilakukan anak bersamaan dengan narapidana lainnya yang baru masuk faktor pemasyarakatan. Selain sosialisasi terkait kesadaran berbangsa dan bernegara yang diberikan pada saat masa orientasi, Lapas Anak Kendari juga megadakan kegiatan kepramukaan. Kegiatan kepramukaan ini diberikan khusus bagi Anak. Tujuan dari diadakannya kegiatan kepramukaan ini adalah untuk membentuk kedisiplinan dan kesadaran berbangsa dan bernegara pada diri Anak.

Untuk mengetahui pelaksanaan pembinaan kesadaran berbangsa dan bernegara, dapat dilihat pada tabel di bawah ini:

Tabel 6 Pelaksanaan Pembinaan Kesadaran Berbangsa Dan Bernegara

\begin{tabular}{clcc} 
No. & \multicolumn{1}{c}{ Pernyataan } & Frekuensi & Persentase (\%) \\
\hline $\mathbf{1}$ & Selalu Dilaksanakan & 34 & 75,77 \\
$\mathbf{2}$ & Kadang-kadang Dilaksanakan & 6 & 16,33 \\
3 & Jarang Dilaksanakan & 2 & 4,44 \\
4 & Tidak pernah Dilaksanakan & - & - \\
5 & Ragu-Ragu/Tidak Tahu & 3 & 6,66 \\
\hline & J u $\mathbf{~ m ~ l ~ a ~ h ~}$ & $\mathbf{4 5}$ & $\mathbf{1 0 0}, \mathbf{0 0}$ \\
\hline
\end{tabular}

Sumber: Data primer yang diolah, 2020

Berdasarkan data di atas menggambarkan bahwa Sebagian besar responden menyatakan bahwa pembinaan kesadaran berbangsa dan bernegara selalu dilaksanakan dengan persentase 75,77 \%. Berdasarkan wawancara dengan Menurut Herianto, Kepala Seksi Bimbingan Napi dan Anak Didik, Lembaga Pemasyarakatan (Lapas) Kelas IIA Kendari, bahwa pembinaan pembinaan kesadaran berbangsa dan bernegara meliputi: wawasan kebangsaan, cinta tanah air, dan nilai-nilai Pancasila (Wawancara, 23 Februari 2020).

Pada pembinaan kesadaran berbangsa dan bernegara, diberikan program Pramuka yakni berupa baris-berbaris, upacara bendera, membuat tenda, Dasadharma Pramuka dan berbagai macam kegiatan-kegiatan kepramukaan yang bertujuan untuk membina kesadaran para pemuda sebagai generasi penerus bangsa yang dengan darah, akal, dan hati, siap untuk membela dan mempertahankan kemerdekaan, persatuan dan kedaulatan dalam berbangsa dan bernegara, dalam hal ini Negara Kesatuan Republik Indonesia (NKRI). 


\section{Pembinaan Kemandirian}

Program-program kemandirian yang ada di LPKA, Lapas dan Rutan merupakan program yang telah diputuskan oleh jajaran Kementerian Hukum dan Hak Asasi Manusia melalui Direktorat Jenderal Pemasyarakatan. Namun, program-program tersebut juga disesuaikan dengan kondisi lingkungan di sekitar LPKA, Lapas dan Rutan.

Pembinaan kemandirian ini meliputi pembinaan keterampilan. LPKA/Lapas dan Rutan melaksanakan kegiatan pembinaan kemandirian keterampilan tujuan diselenggarakannya kegiatan tersebut adalah mempersiapkan Warga Binaan agar hidup mandiri melalui keterampilan sehingga memiliki nilai jual/ekonomi dan fungsi tidak bagi diri mereka pribadi, namun juga dapat meningkatkan pendapatan keluarga bahkan bagi Lembaga Pemasyarakatan dan masyarakat pada umumnya, terutama setelah mereka selesai menjalani masa pidana hukuman nanti.

Pembinaan kemandirian diberikan melalui program-program, yaitu: keterampilan untuk mendukung usaha mandiri, misalnya kerajinan tangan, industri rumah tangga, reparasi mesin dan alat-alat elektronika dan sebagainya; Keterampilan untuk mendukung usaha industri kecil, misalnya pengelolaan bahan mentah dari sektor pertanian dan bahan alam menjadi bahan setengah jadi dan menjadi bahan jadi.

Untuk mengetahui pelaksanaan pembinaan keterampilan ini, dapat dilihat pada table di bawah ini:

Tabel 7. Pelaksanaan Pembinaan Keterampilan

\begin{tabular}{clcc} 
No. & \multicolumn{1}{c}{ Pernyataan } & Frekuensi & Persentase (\%) \\
\hline 1 & Selalu Dilaksanakan & 5 & 11,11 \\
2 & Kadang-kadang Dilaksanakan & 24 & 53,33 \\
3 & Jarang Dilaksanakan & 14 & 31,11 \\
4 & Tidak pernah Dilaksanakan & - & - \\
5 & Ragu-Ragu/Tidak Tahu & $\mathbf{2}$ & 4,44 \\
\hline & J u m l a h & 45 & $\mathbf{1 0 0 , 0 0}$ \\
\hline
\end{tabular}

Sumber: Data primer yang diolah, 2020

Berdasarkan data di atas menggambarkan bahwa Sebagian besar responden menyatakan bahwa pembinaan keterampilan kadang-kadang dilaksanakan dengan persentase 53,33\%. Pembinaan keterampilan yand dilakukan di LPKA, Lapas dan Rutan meliputi perikanan, peternakan, pertanian, perkebunan, industri dan Jasa seperti meubel, cukur/pangkas rambut/salon kecantikan, pencucian kendaraan, jahit, laundry, pembuatan keset, pembuatan bingkai foto, pres ban dan bimbingan kerja dan kerja lingkungan.

Pembinaan ketrampilan penting untuk diberikan kepada anak agar mereka melakukan kegiatan yang bermanfaat di dalam lembaga. Karena setelah keluar dari lembaga pemasyarakatan atau dikatakan bebas, sedikit sekolah formal yang kembali menerima mantan narapidana anak. Sehingga jika tidak dibekali dengan ketrampilan-ketrampilan yang bermanfaat, maka mantan narapidana anak akan menjadi pengangguran yang tidak bisa melakukan apapun. Dengan ketrampilan yang diperoleh selama masa tahanan, setidaknya anak bisa mengembangkan bakatnya tersebut dirumah atau lingkungannya tempat ia kembali nanti. Hasil karyanya pun bisa dijual dan menghasilkan uang atau dimanfaatkan sendiri dirumahnya. 
Lembaga Pembinaan Khusus Anak Kendari mengharapkan warga binaannya berperilaku produktif selama di dalam tahanan supaya tidak hanya terpuruk dengan hukumannya. Narapidana anak sebagai warga masyarakat dan sebagai warga negara berhak untuk mendapatkan pendidikan secara adil, maka mereka perlu diberikan pendidikan yang programnya disesuaikan dengan kondisi serta keberadaan mereka.

Berdasarkan uraian pembinaan di atas, dikaitkan dengan teori-teori yang ada bahwa permasalahan yang dihadapi anak yang berkonflik dengan hukum bisa terjadi pada tiga tahap, yaitu tahap pra-adjudikasi, adjudikasi dan pascaadjudikasi. Pada tahap pra-adjudiksi, masalah yang dihadapi antara lain minimnya upaya diversi pada tahap awal proses peradilan pidana, tidak adanya rutan khusus anak yang mengakibatkan percampuran antara tahanan anak dan tahanan dewasa, belum terpenuhinya hak-hak dasar anak seperti kualitas makanan, pendidikan, standar kesehatan, sanitasi dan sebagainya. Pada tahap adjudikasi, masalah yang dihadapi antara lain anak dengan kasus ringan maupun berat tetap di proses sampai ke pengadilan, minimnya putusan non penjara.

Pada tahap pascaa djudikasi, masalah yang dihadapi antara lain terjadi di beberapa daerah, jumlah dan kondisi penjara khusus anak belum memadai, bahkan seringkali anak-anak disatukan dengan narapidana dewasa, sehingga menimbulkan kerentanan terhadap pelanggaran hak sebagai anak didik dan sebagai anak, belum terpenuhinya dengan baik hakhak anak didik pemasyarakatan seperti kualitas makanan, pendidikan, standar kesehatan, ibadah, rekreasi, kunjungan dan lainnya. Hal ini tentu sangat memprihatinkan mengingat anak-anak adalah generasi penerus bangsa yang diharapkan kelak akan menjadi pemimpin negeri ini. Oleh sebab itu perlindungan hukum terhadap anak-anak yang berkonflik dengan hukum tentunya menjadi perhatian serius bagi seluruh elemen bangsa terutama pemerintah untuk memberikan perlindungan kepada anak-anak tersebut.

Menurut pemidanaan khsusnya teori pembinaan, tujuan pemidanaan adalah untuk merubah tingkah laku/kepribadian narapidana agar ia meninggalkan kebiasaan buruk yang bertentangan dengan norma-norma hukum serta norma-norma lainnya dan agar ia lebih cenderung untuk mematuhi norma-norma yang berlaku. Teori pembinaan lebih diarahkan pada perbaikan narapidana, bukan pada tindak pidana yang telah terjadi. Sehingga pelaku tindak pidana tidak mengulangi lagi perbuatannya dan dapat diterima di masyarakat.

Menurut Packer, bahwa pembenaran yang paling langsung menarik untuk hukuman adalah klaim bahwa hal itu dapat digunakan untuk mencegah kejahatan dengan begitu mengubah kepribadian pelanggar sehingga dia akan menyesuaikan diri dengan aturan hukum; dengan kata lain mereformasi para pelaku (The most immediately appealing justification for punishment is the claim that it may be used to prevent crime by so changing the personality of the offender that he will conform to the dictates of law; in word, by reforming him).

Berkaitan tujuan pemidanaan anak yaitu untuk memberikan perlindungan dan mewujudkan kesejahteraan anak yang pada dasarnya merupakan bagian dari kesejahteraan sosial. Ini tidak berarti bahwa kesejahteraan atau kepentingan anak berada di bawah kepentingan masyarakat, tetapi justru harus dilihat bahwa mengutamakan kesejahteraan dan kepentingan anak itu pada hakekatnya merupakan bagian dari usaha mewujudkan kesejahteraan sosial.

Menurut Muladi dan Barda Nawawi Arief, pendekatan khusus dalam menangani masalah hukum dan peradilan anak antara lain: 
1. Anak yang melakukan tindak pidana/kejahatan (juvenile offender) janganlah dipandang sebagai seorang penjahat (criminal), tetapi harus dilihat sebagai orang yang memerlukan bantuan, pengertian dan kasih sayang. 2. Pendekatan yuridis terhadap anak hendaknya lebih mengutamakan pendekatan persuasif-edukatif dan pendekatan kejiwaan (psikologis) yang berarti sejauh mungkin menghindari proses hukum yang semata-mata bersifat menghukum, yang bersifat degradasi mental dan penurunan semangat (discouragement) serta menghindari proses stigmatisasi yang dapat menghambat proses perkembangan, kematangan dan kemandirian anak dalam arti yang wajar.8 Beberapa peraturan perundang-undangan yang masih memikirkan masa depan bagi anak yang berkonflik dengan hukum diantaranya Undang-Undang Nomor 12 Tahun 1995 tentang Pemasyarakatan (UU Pemasyarakatan), UU Perlindungan Anak dan UU SPPA. Hal ini sejalan dengan Pasal 28C Ayat (1) UUD Negara Republik Indonesia Tahun 1945 bahwa "Setiap orang berhak mengembangkan diri melalui pemenuhan kebutuhan dasarnya, berhak mendapat pendidikan dan memperoleh manfaat dari ilmu pengetahuan dan teknologi, seni dan budaya, demi meningkatkan kualitas hidupnya dan demi kesejahteraan umat manusia."Kemudian dalam peraturan-peraturan PBB juga diatur mengenai perlindungan remaja yang kehilangan kebebasannya, di mana dijelaskan bahwa remaja yang kehilangan kebebasannya berhak memperoleh: 8 Muladi dan Barda Nawawi Arief, Bunga Rampai Hukum Pidana, Alumni, Bandung, 1992, hlm. 115. (a) Pendidikan, (b) Latihan keterampilan dan latihan kerja, (c) Rekreasi, (d) Memeluk agama, (e) Mendapatkan perawatan kesehatan, (f) Pemberitahuan tentang kesehatan, (g) Berhubungan dengan masyarakat luas.9 Undang-Undang Nomor 12 Tahun 1995 tentang Pemasyarakatan dalam Pasal 1 Angka 1 menyatakan bahwa: "Pemasyarakatan adalah kegiatan untuk melakukan pembinaan warga binaan pemasyarakatan berdasarkan sistem, kelembagaan dan cara pembinaan yang merupakan bagian akhir dari sistem pemidanaan dalam tata peradilan pidana." Dari pengertian tersebut dapat diketahui bahwa inti dari pemasyarakatan adalah pembinaan terhadap narapidana supaya nantinya dapat kembali ke masyarakat dengan baik. Untuk dapat melakukan pembinaan itu diperlukan suatu sistem yang dinamakan sistem pemasyarakatan. Batasan tentang sistem pemasyarakatan yaitu suatu tatanan mengenai arah dan batas serta cara pembinaan pemasyarakatan berdasarkan Pancasilaı yang dilaksanakan secara terpadu antara pembina, yang dibina dan masyarakat untuk meningkatkan kualitas warga binaan pemasyarakatan agar menyadari kesalahan, memperbaiki diri dan tidak mengulangi tindak pidana, sehingga dapat diterima kembali oleh lingkungan masyarakat, dapat aktif berperan dalam pembangunan dan dapat hidup secara wajar sebagai warga yang baik dan bertanggung jawab. Dalam sistem tersebut, pihak-pihak yang berhubungan bukan hanya antara pembina dengan yang dibina, melainkan juga dengan pihak masyarakat. Hubungan segitiga ini dilaksanakan secara terpadu, dengan tujuan untuk meningkatkan orang-orang yang dibina.

\section{KESIMPULAN}

Pelaksanaan pembinaan narapidana anak pada lembaga pemasyarakatan di Provinsi Sulawesi Tenggara yang meliputi pembinaan kepribadian dan kemandirian belum optimal dilakukan, hal itu akan memberikan dampak yang kurang baik kepada anak narapidana ketika melakukan reintegrasi dengan masyarakat yang diberi stigma negatif oleh masyarakat. 


\section{SARAN}

1. Hendaknya para Pimpinan di instansi LPKA, Lapas dan Rutan untuk memaksimalkan Kerjasama dengan intansi terkait dalam rangka pembinaan narapidana anak dalam menjalani hukuman pada lembaga pemasyarakatan di Provinsi Sulawesi Tenggara.

2. Perlu mengoptimalkan keadilan restoratif kepada pelaksana/penegak hukum (Polisi, Jaksa, Hakim serta BAPAS) agar anak tidak menjadi terpidana dalam rangka menghindari stigma negatif masyarakat.

\section{DAFTAR PUSTAKA}

Amran, E., Pawennei, M., \& Zainuddin, Z. (2020). Efektivitas Penyidikan Korban Tindak Pidana Kekerasan Terhadap Anak. Journal of Lex Theory (JLT), 1(2), 181-195.

Candra, E. (2020). Implementasi Kewajiban Pembinaan Terhadap Pidana Anak Di Lembaga Pembinaan Khusus Anak Pekanbaru Berdasarkan Undang-Undang Republik Indonesia Nomor 11 Tahun 2012 Tentang Sistem Peradilan Pidana Anak. Widya Yuridika: Jurnal Hukum, 3(2), 343-362.

Erwandi, E. (2020). PK Bapas dalam Penyelesaian Anak yang Berkonflik dengan Hukum Sesuai Amanat UU SPPA. Jurnal Pemikiran Dan Pengembangan PembelajaraN, 2(2), 35-40.

Fitriani, R. (2016). Peranan Penyelenggara Perlindungan Anak Dalam Melindungi Dan Memenuhi Hak-Hak Anak. Jurnal Hukum Samudra Keadilan, 11(2), 250-358.

Haling, S., Halim, P., Badruddin, S., \& Djanggih, H. (2018). Perlindungan Hak Asasi Anak Jalanan Dalam Bidang Pendidikan Menurut Hukum Nasional Dan Konvensi Internasional. Jurnal Hukum E Pembangunan, 48(2), 361-378.

Haryaningsih, S., \& Hariyati, T. (2020). Resosialisasi di lembaga pemasyarakatan khusus anak. Jurnal Konseling dan Pendidikan, 8(3), 191-197.

Michael, D. (2017). Penerapan Hak-Hak Narapidana di Lembaga Pemasyarakatan Klas IA Tanjung Gusta, Sumatera Utara Ditinjau dari Perspektif Hak Asasi Manusia. Jurnal penelitian hukum DE JURE, 17 (2), 249-263.

Ningtias, D. R., Sampara, S., \& Djanggih, H. (2020). Diversi Sebagai Bentuk Penyelesaian Perkara Pidana Anak. Journal of Lex Generalis (JLG), 1(5), 633-651.

Nugroho, O. C. (2017). Peran Balai Pemasyarakatan pada Sistem Peradilan Pidana Anak ditinjau Dalam Perspektif Hak Asasi Manusia. Jurnal HAM, 8(2), 161-174.

Rukmana, I. (2020). Implementasi Pembinaan Narapidana Terorisme Di Lembaga Pemasyarakatan Dalam Kerangka Deradikalisasi. Syntax Literate; Jurnal Ilmiah Indonesia, 5(9), 861-873.

Situmorang, V. H., HAM, R., \& Kav, J. H. R. S. (2019). Lembaga Pemasyarakatan sebagai Bagian dari Penegakan Hukum. Jurnal Ilmiah Kebijakan Hukum, 13(1), 85-98.

Wibowo, A. (2018). Pemahaman Situasi Anak Yang Berkonflik Dengan Hukum Pada Lembaga Pemasyarakat Orang Dewasa. Journal of Social Welfare, 19(2), 159-181 